Crop Breeding and Applied Biotechnology 12: 25-33, 2012

Brazilian Society of Plant Breeding. Printed in Brazil

\title{
ARTICLE
}

\section{Value for cultivation and use of upland rice cultivars tested in multi- environments}

Vanderley Borges ${ }^{2 *}$, Antônio Alves Soares ${ }^{3}$, Marcos Deon Vilela de Resende ${ }^{4}$, Moizés de Sousa Reis ${ }^{5}$, Vanda Maria de Oliveira Cornelio ${ }^{5}$, Natália Alves Leite ${ }^{3}$, Plínio César Soares ${ }^{6}$ and Geovani Tadeu Costa Júnior ${ }^{3}$

Received 07 January 2011

Accepted 20 April 2011

\begin{abstract}
Data from 11 years of a breeding program for upland rice of the partner institutions Embrapa arroz e feijão, Epamig and UFLA conducted in 11 regions of Minas Gerais, were analyzed by the mixed model methodology. The genotypic correlations between environments ranged from medium to high, suggesting the predominance of simple interaction, but with differentiated ranking of genotypes at the different locations. Lines with specific performance, as well as lines of broad adaptation were identified. The performance of cultivar BRSMG Caravera, released in 2007, was superior to the others in terms of grain yield at all sites assessed, in other words, broad adaptation, in addition to a high genotypic performance.
\end{abstract}

Key words: Oryza sativa, mixed models, genotypic values.

\section{INTRODUCTION}

The main objective of any improvement program is to breed cultivars. Accordingly, experiments should be conducted at representative locations of the producing regions for the testing and subsequent recommendation of cultivars with specific or broad adaptation. For the release of cultivars in Brazil, the Ministry of Agriculture recommends tests of Value for Cultivation and Use (VCU), which ought to be laid out in a randomized complete block design with speciesspecific number of replications, locations and years (Brazil 2001). In the VCU tests, inferences should be drawn on individual environments, medium environments and new environments outside the experimental network (Resende 2007a). Hence, for a future release of cultivars, it is important to know the correlation between genotypes across the environments, the coefficients of determination of the effects of genotype and of the interactions with other

\footnotetext{
${ }^{2}$ Universidade Federal do Acre, Centro de Ciências Biológicas e da Natureza, C.P.2018, 69.920-900, Rio Branco, AC, Brazil

${ }^{3}$ Universidade Federal de Lavras, Departamento de Agronomia, C.P. 37, 37.200-000, Lavras, MG, Brazil

${ }^{4}$ Embrapa Florestas/Universidade Federal de Viçosa, Departamento de Engenharia Florestal, 36.570-000, Viçosa, MG, Brazil

${ }^{5}$ Empresa de Pesquisa Agropecuária de Minas Gerais, C.P. 176, 37.200-000, Lavras, MG, Brazil

${ }^{6}$ Empresa de Pesquisa Agropecuária de Minas Gerais, C.P. 216, 37.570-000, Viçosa, MG, Brazil
} 
effects such as locations, years, seasons, etc. and of the components of total phenotypic variance.

Based on the magnitude of the correlations between genotypes across the environments the type of interaction and its influence on the classification of genotypes and selection of superior plant material can be determined. The components of variance, in turn, help determine how much each component contributes to the total phenotypic variance. In multi-environment experiments, these components are represented by the genetic variance, variance of genotype - location (GL) interaction, variance of genotype - year (GA) interaction, variance of genotype - location - year (GLA) interaction and by the residual variance.

The statistical-genetic aspects of VCU experiments in Brazil have usually been analyzed using the least squares method. However, in several countries e.g., England and Australia, the mixed model methodology applied in plant research has been used for annual plants (Smith et al. 2005, Smith et al. 2001), Brazil (Carvalho et al. 2008, Fritsche Neto et al. 2008), Canada (Yan and Rajcan 2003) and Germany (Piepho et al. 2007), to select the best genotypes based on their genotypic values for cultivar recommendation. Details on the methodology of mixed models applied in plant experimentation are given by Resende et al. (1996), Smith et al. (2001), Resende (2002, 2007a) and Piepho and Mohring (2005). The use of the mixed model methodology for the recommendation of superior rice genotypes is still scarce.

The aim of this study was to use the mixed model methodology in the tests of cultivation value of upland rice from 1997/98 to 2007/08.

\section{MATERIALAND METHODS}

The results of grain yield used here were obtained in the tests of Value for Cultivation and Use (VCU) of the cooperative improvement program of upland rice, developed in partnership by the partners UFLA (Universidade Federal de Lavras), EPAMIG (Empresa de Pesquisa Agropecuária de Minas Gerais) and Embrapa/CNPAF (Empresa Brasileira de Pesquisa Agropecuária/Centro Nacional de Pesquisa de Arroz e Feijão), from 1997/98 to 2007/08, in Minas Gerais. At 11 different sites, 107 lines were assessed for 11 growing seasons (Table 1 ), using the model: $y_{i j k n}=u+g_{i}+b_{j / k / n}+a_{k}+l_{n}+g a_{i k}+g l_{i n}+g l a_{i n k}+g b a l_{i j / k / n}$ where: $y_{i j k n}$ is the value of the observation of treatment $\mathrm{i}$ in replication $\mathrm{j}$, in year $\mathrm{k}$, at location $\mathrm{n}$; $\mu$ is the general mean; $g_{i}$ is the effect of genotype $\mathrm{i} ; b_{j / k / n}$ is the effect of block $\mathrm{j}$ within year $\mathrm{k}$ at location $\mathrm{n}$; $a_{k}$ is the effect of year of planting $\mathrm{k} ; l_{n}$ is the effect of location $\mathrm{n} ; g a_{i k}$ is the effect of the genotype-year interaction; $g l_{\text {in }}$ is the effect of genotypelocation interaction; $g l a_{i n k}$ is the effect of the genotypelocation-year interaction; $g_{b a l_{i j / k / n}}$ is the random error or residue.

In matrix form, the corresponding model is: $y=X b+Z g+Q g a+T g l+U g l a+e$ where: $y$ is the observation vector; $b$ the vector of effect combinations of block-location-year (fixed effects) added to the general mean; $g$ is the vector of genotypic effects (random effects), ga the vector of effects of genotypesyear interaction (random effects); $g l$ the vector of effects of genotypes-location interaction (random effects); gla the vector of the triple genotypes-location-year interaction (random effects), and $e$ the error vector (random). X, Z, Q, T and U represent the incidence matrices for these effects, respectively.

The effects of year, location and block/year/ location, which are purely environmental effects, were grouped in effect $b$, and the lines were considered unrelated. The structure of means and variances was presented as proposed by Resende (2002, 2007a). The equations of the mixed model for the model adopted are:

$$
\left(\begin{array}{c}
\hat{b} \\
\tilde{g} \\
g \tilde{a} \\
g \tilde{l} \\
g \tilde{l} a
\end{array}\right)=\left(\begin{array}{ccccc}
X^{\prime} X & X^{\prime} Z & X^{\prime} Q & X^{\prime} T & X^{\prime} U \\
Z^{\prime} X & Z^{\prime} Z+I \lambda_{1} & Z^{\prime} Q & Z^{\prime} T & Z^{\prime} U \\
Q^{\prime} X & Q^{\prime} Z & Q^{\prime} Q+I \lambda_{2} & Q^{\prime} T & Q^{\prime} U \\
T^{\prime} X & T^{\prime} Z & T^{\prime} Q & T^{\prime} T+I \lambda_{3} & T^{\prime} U \\
U^{\prime} X & U^{\prime} Z & U^{\prime} Q & U^{\prime} T & U^{\prime} U+I \lambda_{4}
\end{array}\right)^{-1}\left(\begin{array}{l}
X y \\
Z y \\
Q y \\
T y \\
U y
\end{array}\right) \text { where: }
$$

$\lambda_{1}=\frac{\sigma_{e}^{2}}{\sigma_{g}^{2}}=\frac{1-h_{g}^{2}-c_{g a}^{2}-c_{g l}^{2}-c_{g l a}^{2}}{h_{g}^{2}}, \quad \lambda_{2}=\frac{\sigma_{e}^{2}}{\sigma_{g a}^{2}}=\frac{1-h_{g}^{2}-c_{g a}^{2}-c_{g l}^{2}-c_{g a}^{2}}{c_{g a}^{2}}$

$\lambda_{3}=\frac{\sigma_{e}^{2}}{\sigma_{g l}^{2}}=\frac{1-h_{g}^{2}-c_{g a}^{2}-c_{g l}^{2}-c_{g l a}^{2}}{c_{g l}^{2}}$ e $\lambda_{4}=\frac{\sigma_{e}^{2}}{\sigma_{g h}^{2}}=\frac{1-h_{g}^{2}-c_{g s}^{2}-c_{g l}^{2}-c_{g a}^{2}}{c_{g b}^{2}}$ where:

$h_{g}^{2}$ : broad-sense heritability.

$c_{g a}^{2}$ : Coefficient of determination of the effects of genotype-year interaction.

$c_{g l}^{2}$ : Coefficient of determination of the effects of genotype-location interaction.

$c_{\text {gla }}^{2}$ : Coefficient of determination of the effects of genotype-location-year interaction.

The estimation of variance components by REML and prediction of breeding values by BLUP were described by Resende (2002, 2007a). Analyses were 
Value for cultivation and use of upland rice cultivars tested in multi-environments

Table 1. List of growing seasons and experimental locations

\begin{tabular}{ll}
\hline Growing season & Locations \\
\hline $1997 / 98$ & Lambari, Lavras, Patos de Minas \\
$1998 / 99$ & Felixlândia, Lambari, Lavras, Patos de Minas, Patrocínio and Uberaba \\
$1999 / 00$ & Felixlândia, Lambari, Lavras, Paracatu, Patos de Minas, Patrocínio and Uberaba \\
$2000 / 01$ & Felixlândia, Lambari, Lavras, Patos de Minas, Patrocínio and Uberaba \\
$2001 / 02$ & Felixlândia, Lambari, Patos Minas, Uberaba, Uberlândia and Viçosa \\
$2002 / 03$ & Lambari, Lavras, Patos de Minas, Patrocínio, Uberaba, Uberlândia and Viçosa \\
$2003 / 04$ & Felixlândia, Lambari, Patos de Minas, Patrocínio, Piumhi and Viçosa \\
$2004 / 05$ & Felixlândia, Lambari, Lavras, Patos de Minas, Patrocínio and Viçosa \\
$2005 / 06$ & Lambari, Lavras, Patos de Minas, Patrocínio and Piumhi \\
$2006 / 07$ & Lambari, Lavras, Patos de Minas, Patrocínio, Piumhi and São Sebastião do Paraíso \\
$2007 / 08$ & Lambari, Lavras, Patos de Minas, Patrocínio, Piumhi and São Sebastião do Paraíso \\
\hline
\end{tabular}

performed using the program SELEGEN REML/BLUP (Resende 2007b).

\section{RESULTS AND DISCUSSION}

Analysis of deviance indicated statistical significance for all random effects of the model, except for the triple interaction of genotype-location-years (represented for G-L-A) (Table 2). The estimate of the coefficient of determination of the genotypic effects (given by the broad-sense heritability $\left(h_{g}^{2}\right)$ free of the interactions of a given genotype at a given location and year was 0.097 (Table 2). Considering the effects of the interaction, involving genotypes, locations and years together, this value and its deviations are considered low, since it is free of all interactions. In other words, the heritability is not inflated by the interaction G-L, G-A and G-L-A. This was expected and is consistent with the quantitative nature of the trait. However, this deflation was minimal, since all GE interaction components were low.

The coefficients of determination of the effects of genotype-year $\left(c_{g a}^{2}\right)$, genotype -location $\left(c_{g l}^{2}\right)$ and genotype-location-year ( $c_{g l a}^{2}$ ) were, respectively, 0.047, 0.051 and 0.019 , or $4.68 \%, 5.08 \%$ and $1.96 \%$. These values refer to the proportion of total phenotypic variation ( $\mathrm{Vp}$ ) explained by the interaction. Therefore, the interactions G-A and G-L were higher than the triple interaction G-L-A. For this reason, the triple interaction G-L-A influenced Vp less than the interactions of G-A and G-L. For common bean, Carbonell et al. (2007), observed correlation coefficients ranging between 0.165 and 0.325 for 15

Table 2. Analysis of deviance (ANADEV), variance of components and determination coefficients of the global combined analysis of 107 cultivars and lines tested at 11 locations and in 11 years, 1997/1998 to 2007/2008

\begin{tabular}{lcccc}
\hline Effect & Deviance & LRT $\left(\chi^{2}\right)$ & Components of variance & Determination of coefficients \\
\hline Genotype (G) & $19453.87^{+}$ & $15.20^{* *}$ & $57742.19^{* *}$ & $0.09^{* *}$ \\
Genotype-location (G-L) & $19444.21^{+}$ & $5.54^{*}$ & $30266.24^{*}$ & $0.05^{*}$ \\
Genotype-year (G-A) & $19443.79^{+}$ & $5.12^{*}$ & $27878.57^{*}$ & $0.05^{*}$ \\
Genotype-location-year (G-L-A) & $19438.58^{+}$ & 0.08 & 11352.16 & 0.02 \\
Error & & - & 468824.32 & 0.84 \\
\hline Full model & 19438.67 & - & - & 1.00
\end{tabular}

${ }^{+}$: Deviance of the adjusted model without corresponding effects;

* and **: Significant by the chi-square test to $5 \%$ (3.84) and $1 \%$ (6.63) of probability, respectively. 
locations in two years, with values that clearly exceed those found in this study.

The genotypic correlations across environments called rgl, rga,rgl_a,rga_l,rgl_ma, and rga_ml, and rgla were, respectively, 0.656, 0.674, 0.739, 0.759, 0.669, 0.682 , and 0.454 (Table 3 ). These values are considered medium to high (correlation mean 0.66), indicating moderate to high interaction levels. Therefore, the genotypes across environments were not classified exactly equally, ie, the genotypes performed differently in the studied environments. Since most correlation values were close to 0.8 , the interaction was predominantly simple (Cruz and Castoldi 1991). Thus, the cause of this interaction is mainly due to differences in variability between lines in the different environments. This type of interaction causes no problems, since the genotypes that perform best in one environment are the best in others as well (Cruz and Carneiro 2003). The low to medium values of genetic correlations across locations, valid for any year $(\mathrm{rgl})$, indicate a change in genotype ranking at different locations, since a low or medium genetic correlation indicates a high GE interaction, which affects the genotype ranking at the locations. The low magnitude of rgla (0.454) found in this study suggests a moderate level of complex interaction, confirming the assumption that the genotypes performed differently at different locations. Thus, the notably high yields of a given genotype at a particular location were not necessarily as high at others.

The genetic correlation between sites in a given year (rgl_a) was 0.739 , indicating that the genotypes performed very similarly at the sites, which facilitated the selection of lines among locations. Similarly, the genetic correlation over the years, at a given location (rga_l) was 0.759 , indicating that the genotype performance was little affected by the effect of the year. This was somewhat unexpected since upland rice is exposed to very varying weather conditions. The values of the genotypic correlations across locations for the annual mean (rgl_ma) and genotypic correlations across the years for the mean of all locations ( $\left.r g a \_m l\right)$ were moderate (0.669 and 0.682 , respectively). It is therefore important to test the genotypes at several locations and in different years. The slightly higher $r g a \_m l$ over rgl_ma expresses the effect of a slightly lower influence of years than of locations on genotype performance. This finding corroborates the results of Atroch et al. (2000).

For sugarcane, Bastos et al. (2007) studied the trait of brix tons per hectare in seven environments, and found $r g l=0.49$, considered moderate by the authors. For bean grain yield, Carbonell et al. (2007) found $\mathrm{rgl}=0.085$ which, according to Resende (2007a), is a complex type and high interaction. For the trait ton of cane per hectare (TCH) in sugar cane, Oliveira et al. (2005) detected, $r g l=0.62$ at three sites, considered by the authors as medium. In pine, for the trait diameter at breast height (DBH), Pinto Jr. et al. (2006) reported rgl values from 0.63 to 0.76 , considered by the authors as low for the trait, which was confirmed by the determination coefficient of interaction effects, of 0.0099 to 0.0229 . For mate, Sturion and Resende (2005) reported $\mathrm{rgl}=0.402$, in the study interpreted as low genetic correlation and high interaction.

It is important to point out that the predicted genotypic values $(u+g)$ are free of $\mathrm{G}-\mathrm{E}$ interaction and the mean genotypic values at different locations

Table 3. Estimates of the correlations between locations and years for grain yield ( $\mathrm{kg} \mathrm{ha}^{-1}$ ) of 107 rice cultivars and lines tested at 11 locations and in 11 years (1997/1998 to 2007/2008)

\begin{tabular}{lc}
\hline Estimates & Values \\
\hline rgl (genotypic correlation between locations, for any year) & 0.66 \\
rga (genotypic correlation between years, for any location) & 0.67 \\
rgl_a (genotypic correlation between locations, in a given year) & 0.74 \\
rga_1 (genotypic correlation between years, at a given location) & 0.76 \\
rgl_ma (genotypic correlation between locations, for the mean of all years) & 0.67 \\
rga_ml (genotypic correlation between years, for the mean of all locations) & 0.68 \\
rgla (genotypic correlation between locations and years) & 0.45 \\
\hline Overall mean & 3521.72 \\
\hline
\end{tabular}


$(u+g+g e m)$ inflate the mean interaction in all environments (Table 4). Interestingly, the classification of 25 cultivars and lines follows the same order by both criteria $(u+g$ e $u+g+g e m)$. However, based on $u+g+g e m$, the values are higher, exactly by the inclusion of the mean interaction. The predicted genotypic value $(u+g)$ of the best five cultivars and lines (Table 4) for recommendation was $3773.78 \mathrm{~kg} \mathrm{ha}^{-1}$, i.e., an increase of $344.90 \mathrm{~kg} \mathrm{ha}^{-1}$ in the overall mean of all cultivars. To obtain this increase in percentage, it is simply divided by the mean of the group of lines, indicating an increase of $8.92 \%$ by the recommendation of the five cultivars and lines. If only BRSMG Caravera were recommended, the increase would be $12.147 \%$.

Importantly, by the $u+g$ values, cultivars can be recommended for locations that were not tested in the experimental network, since the performance of the genotypes is free of G-E interaction. On the other hand, the recommendation based on $u+g+g e m$ is limited to test sites of the network, or, in the case of other sites, will only be effective if they have the same pattern of $\mathrm{G}-\mathrm{E}$ interaction as evaluated in the experimental net. Otherwise, the recommendation based on the criterion of $u+g$ is safer. The emphasis of this study was the demonstration of the excellent performance of BRSMG Caravera, released in 2007 for cultivation in Minas Gerais. This variety was superior to all other genotypes in terms of grain productivity, suggesting good performance in commercial plantations, with increases of up to $502.17 \mathrm{~kg} \mathrm{ha}^{-1}$ over the overall mean.

An important aspect is that the 25 best genotypes comprise all cultivars recommended for the State of Minas Gerais in the last decade (BRS Primavera, Carisma, BRS Talento, BRS Colosso, BRSMG Conai,

Table 4. Ranking, genotype, genotypic effect $(g)$, predicted genotypic values $(u+g)$, and increase in the general mean of the cultivars and the mean genotypic values in the different environments $(u+g+g e m)$, considering the 107 genotypes, 11 locations and 11 growing seasons $(1997 / 98$ to $2007 / 08)$

\begin{tabular}{|c|c|c|c|c|c|}
\hline Ranking & Line & g & $\mathbf{u}+\mathbf{g}$ & Increase & u+g+gem \\
\hline 1 & BRSMG Caravera & 502.17 & 4023.89 & 502.168 & 4047.82 \\
\hline 2 & Curinga-3 & 436.06 & 3957.78 & 469.11 & 3978.56 \\
\hline 3 & MG 1089 & 273.61 & 3795.32 & 403.94 & 3808.35 \\
\hline 4 & MG 1097 & 260.63 & 3782.35 & 368.11 & 3794.77 \\
\hline 5 & CNA 8436 & 252.06 & 3773.78 & 344.90 & 3785.79 \\
\hline 6 & BRA 01506 & 221.40 & 3743.12 & 324.31 & 3753.67 \\
\hline 7 & CNA 8983 & 220.00 & 3741.73 & 309.41 & 3752.21 \\
\hline 8 & Guarani & 209.53 & 3731.25 & 296.93 & 3741.24 \\
\hline 9 & Carisma & 198.67 & 3720.39 & 286.01 & 3729.85 \\
\hline 10 & CNA 8536 & 195.32 & 3717.04 & 276.94 & 3726.35 \\
\hline 11 & CNA 01596 & 192.84 & 3714.56 & 269.29 & 3723.75 \\
\hline 12 & BRS Colosso & 188.62 & 3710.34 & 262.57 & 3719.32 \\
\hline 13 & CNA 8824 & 183.27 & 3704.99 & 256.47 & 3713.72 \\
\hline 14 & CRO 97505 & 179.34 & 3701.05 & 250.96 & 3709.60 \\
\hline 15 & CNA10227 & 178.72 & 3700.44 & 246.14 & 3708.95 \\
\hline 16 & IAC 202 & 177.60 & 3699.32 & 241.86 & 3707.78 \\
\hline 17 & CNA 8541 & 176.74 & 3698.46 & 238.03 & 3706.88 \\
\hline 18 & BRS Primavera & 176.63 & 3698.32 & 234.61 & 3706.73 \\
\hline 19 & MG 1084 & 168.93 & 3690.65 & 231.16 & 3698.70 \\
\hline 20 & CG3- 118-6 & 155.88 & 3677.60 & 227.39 & 3685.03 \\
\hline 21 & BRS Pepita & 150.37 & 3672.09 & 223.73 & 3679.26 \\
\hline 22 & BRSMG Conai & 146.92 & 3668.64 & 220.24 & 3675.64 \\
\hline 23 & MG 1044 & 143.67 & 3665.39 & 216.91 & 3672.24 \\
\hline 24 & BRS Talento & 137.13 & 3658.85 & 213.58 & 3665.38 \\
\hline 25 & BRSMG Relâmpago & 131.68 & 3653.40 & 210.31 & 3659.67 \\
\hline$\ldots$ & $\ldots$ & $\ldots$ & $\ldots$ & $\ldots$ & $\ldots$ \\
\hline 107 & CNAs 8822 & -414.34 & 3107.38 & 0.00 & 3087.64 \\
\hline
\end{tabular}


BRS Pepita, BRSMG Caravera, and BRSMG Relâmpago), with the only exception BRSMG Curinga. This cultivar, whose cycle is a little late for upland conditions, is more exposed to the effects of the frequent dry spells between February and March. Two other lines that are about to be released are MG 1097 and CG3-118-6 (Table 4). This indicates that the partnership breeding program for upland rice developed in Minas Gerais by UFLA/Epamig/Embrapa Arroz e Feijão was efficient.

Considering the ranking of eight lines, corresponding to genotypic selection per location, in the 11 years of study, the genotypic effects $(g+g e)$ and the predicted genotypic values for each location $(u+g+g e)$, observed that for the five best lines and cultivars, at least four (BRSMG Caravera, Curinga-3, MG 1089 and MG 1097), coincided in at least 7 of the 11 environments with highest mean grain yields. Lines of specific and broad adaptation were also identifed, e.g., the broadly adapted BRSMG Caravera with good performance at eight sites (Lambari, Lavras, Patos de Minas, Patrocínio, Felixlândia, Viçosa, Piumhi, and São Sebastiao do Paraíso), ranking first or second in the ranking per location (Table 5). The three locations where BRSMG Caravera does not stand out are therefore Paracatu, Uberaba and Uberlândia. The reason is that this cultivar was not tested at these three locations, since it was only included in the testing network as of 2003/04, when those sites were no longer part of the test network. Another genotype of broad performance is Curinga-3, a line derived from BRSMG Curinga and included in the tests as of 2004/ 05 and standing out as the best at seven sites (at the same as BRSMG Caravera, except for Sao Sebastião do Paraíso). The absence of Curinga-3 among the most productive at the other four sites (Paracatu, Uberaba, Uberlândia, and São Sebastião do Paraíso) was probably due to the fact that it was not tested there. This line was discarded in view of the characteristics high gelatinization temperature and low amylose content that cause clogging of the cooked rice.

Site-specific lines were identified in Uberlândia, where BRSMG Conai performed particularly well and CNA 8436 in Uberaba and BRA 01596 in Sao Sebastião do Paraíso. The exploitation of the favorable effects of G-E interaction requires the use of the most adapted line for each environment (Chaves 2002). At locations where the first three genotypes coincided (Lambari, Patos de Minas and Piumhi) the values of the new mean or improved mean and selection gains of BRSMG Caravera, Curinga-3 and MG 1089, differed (3609.31 kg $\mathrm{ha}^{-1}, 4195.37 \mathrm{~kg} \mathrm{ha}^{-1}$ and $4038.09 \mathrm{~kg} \mathrm{ha}^{-1}$, respectively). Patos de Minas and Piumhi contribute to higher and similar mean genotypic values, although the increase, considering these three lines, was lower than in Lambari. This was based on the values of $g+g e$, which were superior in Lambari (Table 5).

Paracatu is the location where the mean genotypic value of the genotypes was third-lowest $\left(258.57 \mathrm{~kg} \mathrm{ha}^{-1}\right)$ for the five best genotypes, only ahead of Uberaba (254.02 kg ha-1) and Uberlândia (211.18 kg ha-1), although the predicted genotypic values $(u+g+g e)$ were highest (5629.40 kg ha-1 and $5682.43 \mathrm{~kg} \mathrm{ha}^{-1}$, respectively). Thus, in Paracatu the genotype yield is most positively influenced and the interaction is most exploited. However, the highest mean increase was observed in Lambari (440.87 kg ha-1 for the five best), although their genotypic values were intermediate, compared with other locations. BRSMG Caravera was most often ranked first in the classification, when considering all sites, followed by Curinga-3, MG1089, CNA8436 and MG1097. The performance of these genotypes confirmed the highest genotypic values predicted for each site (Table 5).

Dias and Resende (2001) and Fritsche Neto et al. (2008) emphasized that the REML method allows an efficient use of the data obtained in the proper breeding programs, which as a rule, are unbalanced; and that REML or BLUP are considered optimal to predict breeding values. In view of its accuracy and precision, the REML/BLUP (or mixed models methodology) is highly useful for data analysis in VCU tests of plant breeding programs, particularly in the selection or dropping of lines for each growing season, especially with different numbers of locations, years, replications, and treatments, resulting in non-orthogonal data.

\section{ACKNOWLEDGEMENTS}

The authors are thankful for the funding of the research by the Conselho Nacional de Pesquisa (CNPq), Empresa Brasileira de Pesquisa (Embrapa Arroz e Feijão), Empresa de Pesquisa Agropecuária de Minas Gerais (EPAMIG) and Fundação de Amparo à Pesquisa do Estado de Minas Gerais (Fapemig). 


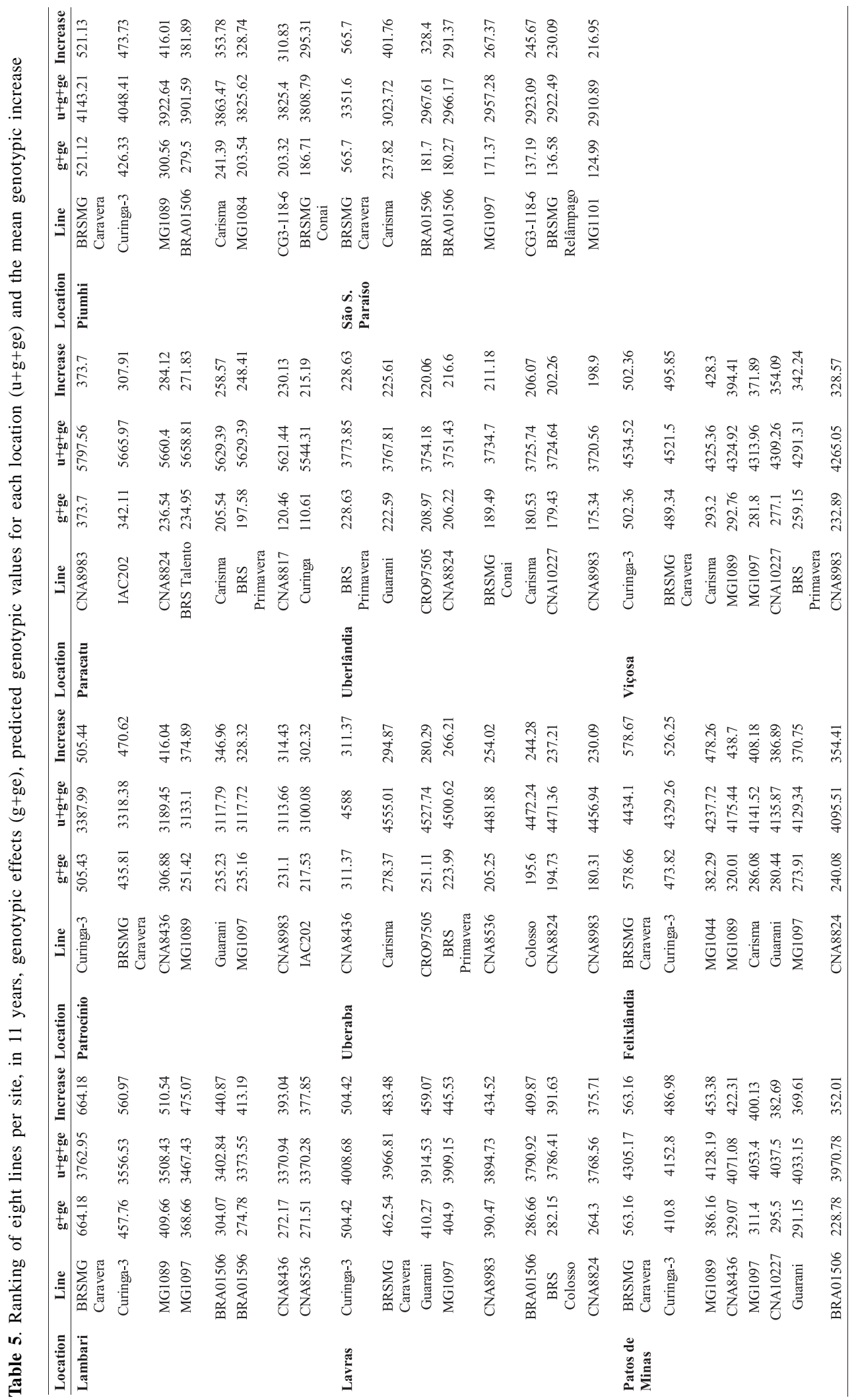




\section{Experimentos de valor de cultivo e uso de arroz de terras altas}

Resumo - Dados de 11 anos do programa de melhoramento de arroz de terras altas das parceiras Embrapa arroz $e$ feijão, Epamig e UFLA conduzidos em 11 municípios de Minas Gerais, foram analisados via metodologia de modelos mistos. As correlações genotípicas por meio dos ambientes apresentaram magnitudes que oscilaram de média a alta, sugerindo a predominância da interação simples, porém, com ordenamento diferenciado dos genótipos nos vários locais. Houve linhagens de comportamento específico, assim como linhagens de comportamento amplo. O cultivar BRSMG Caravera, lançada em 2007, foi superior aos demais no quesito produtividade de grãos em relação a todos os locais avaliados possuindo comportamento amplo além de alto desempenho genotípico.

Palavras-chave: Oryza sativa, modelos mistos, valor genotípico.

\section{REFERENCES}

Atroch AL, Soares AA and Ramalho MAP (2000) Adaptabilidade e estabilidade de linhagens de arroz de sequeiro testadas no estado de Minas Gerais. Ciência e Agrotecnologia 24: 541-548.

Bastos IT, Barbosa MHP, Resende MDV, Peternelli LA, Silveira LCI, Donda LR, Fortunato AA, Costa PMA and Figueiredo ICR (2007) Avaliação da interação genótipo x ambiente em cana-de-açúcar via modelos mistos. Pesquisa Agropecuária Tropical 37: 195-203.

Brasil (2001) Ministério da Agricultura e Abastecimento. Registro Nacional de Cultivares (RNC). Requisitos mínimos para determinação do valor de cultivo e uso, para a inscrição no RNC. (Informe técnico. Anexo IV, 19).

Carbonell SAM, Chiorato AF, Resende MDV, Dias LAS, Beraldo ALA and Perina EF (2007) Estabilidade de cultivares e linhagens de feijoeiro em diferentes ambientes no estado de São Paulo. Bragantia 66: 193-201.

Chaves LJ (2002) Interação de genótipos com ambiente. In Nass LL, Valois ACC, Melo IS and Valadares-Igles MC (eds.) Recursos genéticos e melhoramento: plantas. Fundação MT, Rondonópolis, 673-713.

Carvalho AD, Fritsche Neto R and Geraldi IO (2008) Estimation and prediction of parameters and breeding values in soybean using REML/BLUP and Least Squares. Crop Breeding and Applied Biotechnology 8: 230-235.

Cargnelutti Filho A and Storck L (2007) Estatísticas de avaliação da precisão experimental em ensaios de cultivares de milho. Pesquisa Agropecuária Brasileira 42: 17-24.

Cruz CD and Castoldi FL (1991) Decomposição da interação genótipos $\mathrm{x}$ ambientes em partes simples e complexa. Revista Ceres 38: 422-430.

Cruz CD and Carneiro PCS (2003) Modelos biométricos aplicados ao melhoramento genético. v. 2., Editora UFV, Viçosa, 585p.
Dias LAS and Resende MDV (2001) Estratégias e métodos de seleção. In Dias LAS (ed) Melhoramento genético do cacaueiro. FUNAPE/UFG, Viçosa, p. 217-287.

Fritsche Neto R, Gonçalves MC, Vencovsky R and Souza Júnior CL (2010) Prediction of genotypic values of maize hybrids in unbalanced experiments. Crop Breeding and Applied Biotechnology 10: 32-39.

Oliveira RA, Resende MDV, Daros E, Bespalhok Filho JC, Zambon JLC, Ido OT, Weber $\mathrm{H}$ and Koehler HS (2005) Genotypic evaluation and selection of sugarcane clones in three environments in the state of Paraná. Crop Breeding and Applied Biotechnology 5: 426-434.

Pinto Júnior JE, Sturion JÁ, Resende MDV and Ronzelli Júnior P (2006) Avaliação simultânea de produtividade, adaptabilidade e estabilidade de Eucalyptus grandis em distintos ambientes do Estado do São Paulo. Boletim de Pesquisa Florestal 53: 79-108.

Piepho HP, Mohring J, Melchinger AE and Buchse A (2008) BLUP for phenotypic selection in plant breeding and variety testing. Euphytica 161: 209-228.

Piepho HP and Mohring J (2005) Best linear unbiased prediction of cultivar effects for subdivided target regions. Crop Science 45: 1151-1159.

Resende MDV and Duarte JB (2007) Precisão e controle de qualidade em experimentos de avaliação de cultivares. Pesquisa Agropecuária Tropical 37: 182-194.

Resende MDV, Prates DF, Jesus A and Yamada CK (1996) Estimação de componentes de variância e predição de valores genéticos pelo método da máxima verossimilhança restrita (REML) e melhor predição linear não viciada (BLUP) em Pinus. Boletim de Pesquisa Florestal 32/33: 18-45. 
Resende MDV (2002) Genética biométrica e estatística no melhoramento de plantas perenes. Embrapa Informação Tecnológica, Brasília, 975p.

Resende MDV (2007a) Matemática e estatística na análise de experimentos e no melhoramento genético. Embrapa Florestas, Colombo, 561p.

Resende MDV (2007b) SELEGEN-REML/BLUP: sistema estatístico e seleção genética computadorizada via modelos lineares mistos. Embrapa Florestas, Colombo, 361p.

Smith AB, Cullis BR and Thompson R (2005) Analysis of crop cultivar breeding and evaluation trials: an overview of current mixed model approaches. Journal of Agricultural Science 143: 449-462.
Smith AB, Cullis BR and Thompson R (2001) Analyzing variety by environment data using multiplicative mixed models and adjustments for spatial field trend. Biometrics 57: 1138-1147 2001.

Sturion JA and Resende MDV (2005) Seleção de progênies de erva-mate (Ilex paraguariensis St. Hil.) para produtividade, estabilidade e adaptabilidade temporal de massa foliar. Boletim de Pesquisa Florestal 50: 37-51.

Yan W and Rajcan I (2003) Prediction of cultivar performance based on single- versus multiple-year tests in soybean. Crop Science 43: 549-555. 